\title{
Mercury Exposure and Associations with Hyperlipidemia and Elevated Liver Enzymes: A Nationwide Cross-Sectional Survey
}

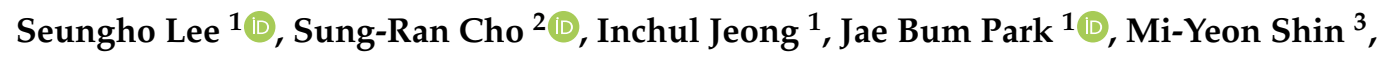

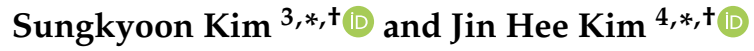 \\ 1 Department of Occupational \& Environmental Medicine, Ajou University School of Medicine, \\ Suwon 16499, Korea; lgydr@aumc.ac.kr (S.L.); icjeong0101@aumc.ac.kr (I.J.); jbpark@ajou.ac.kr (J.B.P.) \\ 2 Department of Laboratory Medicine, Ajou University School of Medicine, Suwon 16499, Korea; \\ sungran@aumc.ac.kr \\ 3 Department of Environmental Health Sciences, Graduate School of Public Health, Seoul National University, \\ Seoul 08826, Korea; damage7@snu.ac.kr \\ 4 Department of Integrative Bioscience \& Biotechnology, Sejong University, Seoul 05006, Korea \\ * Correspondence: ddram2@snu.ac.kr (S.K.); jhkim777@sejong.ac.kr (J.H.K.) \\ + Sungkyoon Kim and Jin Hee Kim contributed equally to this study.
}

Received: 3 June 2020; Accepted: 29 June 2020; Published: 1 July 2020

\begin{abstract}
Mercury $(\mathrm{Hg})$ has obesogenic properties. However, the associated health outcomes of population-level mercury exposure were unclear. This study investigated the relationships between blood mercury levels and obesity-related outcomes such as hyperlipidemia and elevated liver enzymes. Using the second cycle of the Korean National Environmental Health Survey $(n=6454)$, we performed logistic regression to examine the effects of $\mathrm{Hg}$ on hyperlipidemia and elevated liver enzymes. The blood mercury levels were significantly higher in the hyperlipidemia group $(n=3699$, male: $4.03 \mu \mathrm{g} / \mathrm{L}$, female: $2.83 \mu \mathrm{g} / \mathrm{L})$ compared to the non-hyperlipidemia group $(n=2755$, male: $3.48 \mu \mathrm{g} / \mathrm{L}$, female: $2.69 \mu \mathrm{g} / \mathrm{L}$ ), and high blood mercury levels were associated with an $11 \%$ higher risk of hyperlipidemia. The elevated liver enzymes group had higher mean blood mercury levels ( $n=1189$, male: $4.38 \mu \mathrm{g} / \mathrm{L}$, female: $3.25 \mu \mathrm{g} / \mathrm{L})$ than the normal group $(n=5265$, male: $3.64 \mu \mathrm{g} / \mathrm{L}$, female: $2.70 \mu \mathrm{g} / \mathrm{L}$ ), and elevated blood mercury was associated with a $35 \%$ higher risk of elevated liver enzymes. Moreover, the effect was constant after adjusting for personal medications. These results indicate that mercury exposure is significantly associated with hyperlipidemia and elevated liver enzymes.
\end{abstract}

Keywords: mercury; obesogen; lipid profiles; hyperlipidemia; elevated liver enzymes

\section{Introduction}

Obesity is a major risk factor for several chronic diseases, including hypertension, diabetes, and hyperlipidemia, and is a growing concern worldwide. The prevalence of metabolic syndromes in Korea is approximately $30 \%$ due to increasing obesity [1]. A Westernized diet, lifestyle patterns, and exposure to environmental pollutants are involved in the development of obesity. Endocrine-disrupting chemicals such as phthalates, phenols, polychlorinated biphenyl (PCBs), and polybrominated diphenyl ether (PBDEs) are well-known obesogens [2], and several studies have reported that mercury $(\mathrm{Hg})$ is also associated with metabolic syndromes $[3,4]$.

According to the first cycle of the Korean National Environmental Health Survey [5], the geometric mean (GM) of blood $\mathrm{Hg}$ among Koreans was $3.08 \mu \mathrm{g} / \mathrm{L}$, which is high compared to the US (mean: $0.68 \mu \mathrm{g} / \mathrm{L}$ ) [6] and Canada (mean: $0.59 \mu \mathrm{g} / \mathrm{L}$ ) [7]. Blood Hg levels in Korea have been decreasing for the 
last ten years, but approximately $25 \%$ of the Korean population still has high levels over $5.00 \mu \mathrm{g} / \mathrm{L}$, which represents the control value for blood $\mathrm{Hg}$ (HBM-I) [8].

The main reason for high blood $\mathrm{Hg}$ levels in the Korean population is frequent seafood consumption, due to the country's geographical characteristics [9]. A previous study reported that methyl mercury $(\mathrm{MeHg})$ exposure is approaching the reference dose within the Korean population, which is the allowable daily intake [10].

Exposure to $\mathrm{Hg}$ induces oxidative stress, lipid peroxidation, and mitochondrial dysfunction [11,12], and $\gamma$-glutamyltransferase (GGT), a well-known biological marker of oxidative stress, is significantly associated with blood $\mathrm{Hg}$ [13]. Interestingly, GGT levels may reflect insulin resistance [14] and cardiovascular risk because of the relationship with lipoprotein cholesterol oxidation [15]. In a cohort study from Japan, the risk of metabolic syndrome and diabetes increased with the levels of hepatic enzymes, such as alanine aminotransferase (ALT), aspartate aminotransferase (AST), and GGT, among the metabolic syndrome-free participants [16]. Thus, the hepatic enzymes may serve as surrogate markers of obesity.

Several studies have investigated the associations between $\mathrm{Hg}$ and health, but the population-level health effects of $\mathrm{Hg}$ exposure remain unclear. Therefore, we hypothesized that $\mathrm{Hg}$ exposure induces obesity-related outcomes and investigated the relationships between blood $\mathrm{Hg}$ and hyperlipidemia and elevated liver enzymes. We used national biomonitoring data to identify the variables that influence blood $\mathrm{Hg}$ and analyzed the relationships between blood $\mathrm{Hg}$ and the lipid profiles and hepatic enzymes. Finally, we assessed the effects of $\mathrm{Hg}$ on hyperlipidemia and elevated liver enzymes.

\section{Material and Methods}

\subsection{Survey Data}

The Korean National Environmental Health Survey (KoNEHS) is a nationwide cross-sectional biomonitoring survey that aims to monitor the trends of environmental chemicals, including blood $\mathrm{Hg}$, and to identify major exposure sources. Approximately 2000 subjects ( $\geq 19$ years) were annually recruited via stratified multistage sampling units to represent the residential distributions of geographical area, sex, and age. A total of 6454 participants provided blood and urine samples and questionnaire responses, including demographic information and lifestyle. The KoNEHS was approved by the Research Ethics Committee of the National Institute of Environmental Research (NIER \#2014-01-01-074, date of approval: 20 March 2014), Korea. Written informed consents were obtained from all participants. Detailed study information is provided in a prior publication [17]. The present study used data from the second cycle of the KoNEHS, conducted between 2012 and 2014.

\subsection{Measurement}

The participant blood samples were collected in EDTA-containing tubes. After mixing, the blood samples were aliquoted into cryo-tubes and stored at $-20^{\circ} \mathrm{C}$. The blood chemistry markers were measured by Seoul Clinical Laboratories (SCL, Yongin, South Korea), with a reference laboratory service [18]. Briefly, the serum concentrations of total cholesterol, high-density lipoprotein (HDL) cholesterol, and triglycerides (TG) were measured by an enzymatic method using auto analyzer ADVIA 1800 (Siemens Medical Solutions, USA). Serum low-density lipoprotein (LDL) cholesterol concentrations were calculated from Friedewald's equation [19]. Calculated LDL values less than zero were designated as $0(n=37)$. The hepatic enzymes (ALT, AST, and GGT) were measured on an auto-analyzer ADVIA 1800 (Siemens Medical Solutions, Malvern, PA, USA).

Total $\mathrm{Hg}$ was measured by flow injection cold-vapor atomic absorption spectrometry (DMA 80, Milestone, Bergamo, Italy) using whole blood samples. The limit of detection (LOD) for blood $\mathrm{Hg}$ was $0.10 \mu \mathrm{g} / \mathrm{L}$. A value below the LOD $(n=1)$ was included as LOD divided by the square root of 2 . External quality control was performed twice per year by the Korean Association of Quality Assurance 
for Clinical Laboratory (KSLM) and the German External Quality Assessment Scheme for analysis of heavy metals in biological materials (G-EQUAS) [17].

\subsection{Criteria for Hyperlipidemia and Definition of the Elevated Liver Enzymes}

The criteria for hyperlipidemia were taken from the National Cholesterol Education Program-Adult Treatment Panel III (NCEP-ATP III) [20]. Based on these guidelines, hyperlipidemia was defined as lipid profiles showing high LDL (above $130 \mathrm{mg} / \mathrm{dL}$ ), high total cholesterol (above $200 \mathrm{mg} / \mathrm{dL}$ ), or high triglycerides (above $150 \mathrm{mg} / \mathrm{dL}$ ). Elevated liver enzymes were defined by the reference ranges provided by SCL; ALT concentrations above $49 \mathrm{U} / \mathrm{L}$, AST concentrations above $34 \mathrm{U} / \mathrm{L}$, or GGT concentrations above $73 \mathrm{U} / \mathrm{L}$ (for men, above $38 \mathrm{U} / \mathrm{L}$ for women) [21].

\subsection{Statistical Analyses}

Subjects with missing records of blood $\mathrm{Hg}$, lipid profiles, and hepatic enzymes were excluded $(n=24)$. The final dataset contained 6454 personal records, and the distribution of blood $\mathrm{Hg}$ was calculated using sampling weights and survey strata information. The blood $\mathrm{Hg}$ distribution was right-skewed, so a log-transformation was performed to satisfy the assumptions of normality. Bivariate analyses were initially performed to evaluate the demographic variables, including sex (male, female), age group (19-29, 30-39, 40-49, 50-59, 60-69, and >70), BMI (underweight: <18.5, normal: 18.5-23, overweight: 23-25, and obese: $>25$ ), smoking status (non-smoker, past-smoker, or current smoker), alcohol consumption frequency (never, $<1$ time/month, 1-3 times/month, 1-2 times/week, $>3$ times/week, or daily), household monthly income (<USD 1500, USD 1500-USD 3000, USD 3000-USD 5000, USD 5000-USD 10000, and $\geq$ USD 10000), and fish consumption (rarely, 1-3 times/month, 1-3 times/week, or 4-6 times/week). We divided the blood $\mathrm{Hg}$ levels into three groups based on the interquartile range, low (blood $\mathrm{Hg}<25^{\text {th }}$ ), middle $\left(25^{\text {th }} \leq\right.$ blood $\left.\mathrm{Hg}<75^{\text {th }}\right)$, high (blood $\mathrm{Hg} \geq 75^{\text {th }}$ ), and compared the blood lipid levels and hepatic enzymes among groups. Each marker was regressed on blood Hg with sex, age, BMI, smoking status, alcohol frequency, and income using sampling weights and survey strata information. Analysis of variance (ANOVA) by sex and analysis of covariance (ANCOVA) with age were used to assess the associations between blood $\mathrm{Hg}$ and criteria status of each clinical chemistry marker.

Logistic regression analyses were performed to examine the effect of $\mathrm{Hg}$ on hyperlipidemia and elevated liver enzymes. Self-reported personal medications were considered to adjust for the effect of medicine and individual health status. The corresponding health question was open-ended, so we extracted information for hyperlipidemia-associated diseases by including the following terms: 'hyperlipidemia', 'dyslipidemia', 'high blood pressure', 'hypertension', and 'diabetes'. The terms 'fatty liver', 'hepatitis', 'liver cirrhosis', 'liver disease', and 'elevated liver enzymes' were included to represent personal medications for liver diseases. The final models were selected via model fit scores, such as the Akaike information criteria (AIC) and Bayesian information criteria (BIC). The main effects of sex, age, BMI, smoking status, alcohol frequency, and fish consumption, and the two-way interaction of sex and alcohol frequency were included in the final model with the Hg levels. Personal medication information was included in the logistic regression model as a covariate. Finally, the correlations between liver enzymes and lipid profiles were analyzed across the blood Hg groups as part of the sensitivity analysis. The significance level (alpha) was set to 0.05 , and all of the statistical analyses were performed in SAS version 9.4 (SAS Institute Inc., Cary, NC, USA, 2013).

\section{Results}

\subsection{The Distribution of Blood $\mathrm{Hg}$}

The geometric mean (GM) and $95^{\text {th }}$ percentile of blood $\mathrm{Hg}$ among all participants were $3.11 \mu \mathrm{g} / \mathrm{L}$ and $9.01 \mu \mathrm{g} / \mathrm{L}$, respectively. The blood $\mathrm{Hg}$ levels were significantly higher in males $(\mathrm{GM}=3.70 \mu \mathrm{g} / \mathrm{L})$ than in females $(\mathrm{GM}=2.63 \mu \mathrm{g} / \mathrm{L}$; Table 1). Blood $\mathrm{Hg}$ levels increased until the participants were in their 60s. The blood Hg levels also increased as the BMI, alcohol frequency, and household income increased. 
Fish consumption $>4$ times per week was associated with blood $\mathrm{Hg}$ levels that were approximately twice as high as those who rarely ate fish $(\mathrm{GM}=4.04 \mu \mathrm{g} / \mathrm{L}$ vs. $\mathrm{GM}=2.17 \mu \mathrm{g} / \mathrm{L})$. Smoking, alcohol consumption frequency and amount, cooking types, education, marital status, parity, and menopause were also significantly related to blood HG, but herbal medicine had no influence (Supplementary Materials Table S1).

Table 1. Blood Hg distributions by demographic variables ( $\mu \mathrm{g} / \mathrm{L})$.

\begin{tabular}{|c|c|c|c|c|c|c|}
\hline Variables & $\mathbf{N}$ & GM & $95 \%$ Confidence Interval & P75 & P95 & $p$-Value ${ }^{a}$ \\
\hline All & 6454 & 3.11 & $(3.02,3.20)$ & 4.69 & 9.01 & - \\
\hline Sex & & & & & & $<0.0001$ \\
\hline Male & 2767 & 3.70 & $(3.57,3.84)$ & 5.48 & 10.2 & \\
\hline Female & 3687 & 2.63 & $(2.54,2.72)$ & 3.83 & 7.11 & \\
\hline Age & & & & & & $<0.0001$ \\
\hline $19-29$ & 536 & 2.37 & $(2.23,2.52)$ & 3.22 & 6.93 & \\
\hline 30-39 & 1053 & 3.18 & $(3.04,3.33)$ & 4.71 & 8.10 & \\
\hline $40-49$ & 1224 & 3.58 & $(3.43,3.75)$ & 5.25 & 9.56 & \\
\hline $50-59$ & 1434 & 3.64 & $(3.47,3.82)$ & 5.21 & 10.4 & \\
\hline $60-69$ & 1326 & 3.23 & $(3.05,3.43)$ & 4.85 & 9.17 & \\
\hline $70+$ & 881 & 2.54 & $(2.38,2.71)$ & 3.86 & 8.40 & \\
\hline BMI & & & & & & $<0.0001$ \\
\hline$<18.5$ & 159 & 2.13 & $(1.85,2.45)$ & 2.76 & 5.61 & \\
\hline 18.5 to $<23.0$ & 2209 & 2.74 & $(2.64,2.85)$ & 4.08 & 7.61 & \\
\hline 23.0 to $<25.0$ & 1602 & 3.27 & $(3.13,3.41)$ & 4.90 & 9.05 & \\
\hline$\geq 25.0$ & 2484 & 3.54 & $(3.41,3.68)$ & 5.24 & 9.95 & \\
\hline Smoke & & & & & & $<0.0001$ \\
\hline Non-smoker & 4244 & 2.74 & $(2.65,2.83)$ & 4.03 & 7.62 & \\
\hline Past & 1053 & 3.92 & $(3.71,4.14)$ & 5.82 & 11.0 & \\
\hline Current & 1157 & 3.81 & $(3.64,4.00)$ & 5.71 & 10.03 & \\
\hline Alcohol frequency & & & & & & $<0.0001$ \\
\hline Never & 2219 & 2.68 & $(2.57,2.79)$ & 4.07 & 7.49 & \\
\hline$<1$ time/month & 709 & 2.68 & $(2.53,2.84)$ & 3.78 & 6.90 & \\
\hline $1-3$ times/month & 1033 & 2.94 & $(2.79,3.09)$ & 4.28 & 7.83 & \\
\hline 1-2 times/week & 1400 & 3.47 & $(3.30,3.64)$ & 5.25 & 9.67 & \\
\hline$>3$ times/week & 612 & 4.03 & $(3.80,4.27)$ & 5.93 & 11.5 & \\
\hline Daily & 481 & 4.08 & $(3.77,4.43)$ & 5.85 & 13.3 & \\
\hline \multicolumn{4}{|c|}{ Household income (USD/month) } & & & $<0.0001$ \\
\hline$<1500$ & 1792 & 2.76 & $(2.62,2.92)$ & 4.29 & 8.98 & \\
\hline 1500 to $<3000$ & 1621 & 3.01 & $(2.84,3.18)$ & 4.52 & 8.79 & \\
\hline 3000 to $<5000$ & 1765 & 3.21 & $(3.08,3.35)$ & 4.70 & 7.91 & \\
\hline 5000 to $<10,000$ & 1103 & 3.37 & $(3.19,3.56)$ & 5.01 & 9.50 & \\
\hline$\geq 10,000$ & 173 & 3.47 & $(3.06,3.92)$ & 5.19 & 9.97 & \\
\hline \multicolumn{3}{|c|}{ Fish consumption frequency } & & & & $<0.0001$ \\
\hline Rarely & 622 & 2.17 & $(2.03,2.32)$ & 3.07 & 6.95 & \\
\hline $1-3$ times/month & 2030 & 2.88 & $(2.77,2.99)$ & 4.36 & 7.76 & \\
\hline 1-3 times/week & 3377 & 3.41 & $(3.30,3.53)$ & 5.03 & 9.37 & \\
\hline 4-6 times/week & 425 & 4.04 & $(3.68,4.43)$ & 6.20 & 11.2 & \\
\hline
\end{tabular}

Note: $\overline{G M}$, geometric mean; P75, $75^{\text {th }}$ percentile; P95, $95^{\text {th }}$ percentile. ${ }^{a} p$-Value obtained from bivariate analysis (SAS Proc SURVEYREG).

\subsection{The Distribution of Lipid Profiles and Hepatic Enzymes}

The blood $\mathrm{Hg}$ levels were categorized into three groups-low: $\leq 2.36 \mu \mathrm{g} / \mathrm{L}$, medium: $2.36<\mathrm{Hg} \leq 4.07 \mu \mathrm{g} / \mathrm{L}$, and high: $>4.07 \mu \mathrm{g} / \mathrm{L}$. Approximately $45 \%$ of men and $24.6 \%$ of women were in the high blood $\mathrm{Hg}$ group. Table 2 shows the distribution of each marker across the blood $\mathrm{Hg}$ groups. The GMs of LDL, total cholesterol, and TG increased with blood $\mathrm{Hg}$ and was highest in the high blood $\mathrm{Hg}$ group for both sexes. HDL tended to decrease with increasing blood $\mathrm{Hg}$ in all populations, but the trend disappeared after stratifying by sex. The GMs of hepatic enzymes increased with blood $\mathrm{Hg}$ in both sexes, and blood $\mathrm{Hg}$ had a significant effect on all of the markers, except TG. 
Table 2. Lipid profiles and hepatic enzymes among the blood Hg groups.

\begin{tabular}{|c|c|c|c|c|c|c|c|c|c|c|c|c|c|c|}
\hline \multirow{2}{*}{$\begin{array}{l}\text { Biomarkers } \\
\quad \text { (units) }\end{array}$} & \multirow{2}{*}{$\begin{array}{c}\text { Blood Hg } \\
\text { Group }^{a}\end{array}$} & \multicolumn{4}{|c|}{ Male } & \multicolumn{4}{|c|}{ Female } & \multicolumn{4}{|c|}{ All } & \multirow{2}{*}{$p$-Value } \\
\hline & & $\mathbf{N}$ & GM & (P5 & P95) & $\mathbf{N}$ & GM & (P5 & P95) & $\mathbf{N}$ & GM & (P5 & P95) & \\
\hline \multirow{3}{*}{$\begin{array}{c}\text { LDL } \\
\text { (mg/dL) }\end{array}$} & Low & 613 & 82.7 & $(45.3$ & 143) & 1534 & 89.6 & $(52.1$ & 144) & 2156 & 87.3 & $(48.8$ & 143) & \multirow[t]{3}{*}{0.0085} \\
\hline & Middle & 895 & 84.5 & $(40.1$ & 146) & 1236 & 92.3 & $(53.8$ & 150) & 2142 & 88.4 & $(45.8$ & 148) & \\
\hline & High & 1234 & 86.7 & $(40.1$ & 146) & 905 & 91.2 & $(50.0$ & 152) & 2156 & 88.2 & $(43.3$ & 149) & \\
\hline \multirow{3}{*}{$\begin{array}{c}\text { HDL } \\
(\mathrm{mg} / \mathrm{dL})\end{array}$} & Low & 613 & 48.9 & $(33.2$ & 73.6) & 1534 & 56.0 & $(36.5$ & 83.5) & 2156 & 53.6 & $(35.0$ & 80.6) & \multirow[t]{3}{*}{0.0012} \\
\hline & Middle & 895 & 49.6 & (33.6 & $72.8)$ & 1236 & 56.4 & (37.8 & 85.8) & 2142 & 52.9 & (34.7 & $80.5)$ & \\
\hline & High & 1234 & 49.2 & $(33.3$ & 72.4) & 905 & 55.7 & $(37.2$ & 84.4) & 2156 & 51.3 & $(34.1$ & 77.1) & \\
\hline \multirow{2}{*}{$\begin{array}{c}\text { Total } \\
\text { cholesterol } \\
(\mathrm{mg} / \mathrm{dL})\end{array}$} & Low & 613 & 171 & $(126$ & 234) & 1534 & 178 & $(129$ & 240) & 2156 & 176 & $(128$ & 238) & \multirow[t]{2}{*}{$<0.0001$} \\
\hline & High & 1234 & 184 & $(132$ & 246) & 905 & 186 & $(137$ & 242) & 2156 & 185 & $(134$ & 245) & \\
\hline \multirow{3}{*}{$\begin{array}{c}\text { TG } \\
(\mathrm{mg} / \mathrm{dL})\end{array}$} & Low & 613 & 139 & $(49.6$ & 370) & 1534 & 119 & $(49.2$ & 303) & 2156 & 125 & $(49.4$ & 331) & \multirow[t]{3}{*}{0.5822} \\
\hline & Middle & 895 & 160 & $(63.2$ & 496) & 1236 & 127 & $(49.2$ & $365)$ & 2142 & 143 & $(56.5$ & 415) & \\
\hline & High & 1234 & 176 & $(72.8$ & 461) & 905 & 134 & $(53.8$ & 393) & 2156 & 160 & $(62.6$ & 437) & \\
\hline \multirow{3}{*}{$\begin{array}{l}\text { ALT } \\
\text { (U/L) }\end{array}$} & Low & 613 & 22.2 & $(10.3$ & $62.4)$ & 1534 & 16.5 & $(8.54$ & $33.8)$ & 2156 & 18.2 & $(8.99$ & 42.7) & \multirow[t]{3}{*}{0.0002} \\
\hline & Middle & 895 & 25.5 & (11.7 & 71.6) & 1236 & 18.1 & $(9.39$ & $38.2)$ & 2142 & 21.5 & $(10.0$ & $55.4)$ & \\
\hline & High & 1234 & 27.4 & (12.6 & 69.7) & 905 & 19.7 & (9.93 & $45.0)$ & 2156 & 24.5 & (11.1 & 60.9) & \\
\hline $\begin{array}{l}\text { AST } \\
\text { (U/L) }\end{array}$ & Low & 613 & 24.0 & $(16.0$ & 39.1) & 1534 & 21.4 & $(14.1$ & 32.9) & 2156 & 22.2 & $(14.6$ & 34.9) & 0.0226 \\
\hline \multirow{3}{*}{$\begin{array}{l}\text { GGT } \\
\text { (U/L) }\end{array}$} & Low & 613 & 25.7 & $(11.1$ & 106) & 1534 & 15.9 & (7.93 & 41.7) & 2156 & 18.6 & $(8.36$ & $56.5)$ & \multirow[t]{3}{*}{$<0.0001$} \\
\hline & Middle & 895 & 32.6 & (12.6 & 132) & 1236 & 17.8 & $(8.60$ & 51.5) & 2142 & 24.0 & $(9.46$ & 88.7) & \\
\hline & High & 1234 & 39.2 & (13.9 & 152) & 905 & 19.9 & (9.04 & 58.2) & 2156 & 31.1 & (10.7 & 134) & \\
\hline
\end{tabular}

Note: GM, geometric mean; P5, $5^{\text {th }}$ percentile; P95, $95^{\text {th }}$ percentile. ${ }^{a}$ Blood $\mathrm{Hg}$ was categorized into three groups - low: $\leq 2.36 \mu \mathrm{g} / \mathrm{L}, \mathrm{middle:} 2.36<\mathrm{Hg} \leq 4.07 \mu \mathrm{g} / \mathrm{L}$, or high: $>4.07 \mu \mathrm{g} / \mathrm{L} .{ }^{b}$ $p$-Values are the significance of blood Hg levels for each clinical marker, and the regression model included sex, age, BMI, smoking frequency, alcohol frequency, and income. 


\subsection{Associations between the Blood Hg Levels and Lipid Profiles}

Table 3 shows the GMs of the blood Hg levels and their associations with the lipid profiles. Blood $\mathrm{Hg}$ increased until LDL levels reached 'Borderline high'. Total cholesterol consistently increased with blood $\mathrm{Hg}$ in females, but the blood $\mathrm{Hg}$ levels decreased with a 'High' total cholesterol classification in males. The blood $\mathrm{Hg}$ levels significantly differed for each lipid profile after being adjusted for sex. However, the significant difference for HDL disappeared after considering age. According to the definitions for hyperlipidemia (LDL $\geq 130 \mathrm{mg} / \mathrm{dL}$, total cholesterol $\geq 200 \mathrm{mg} / \mathrm{dL}$, or TG $\geq 150 \mathrm{mg} / \mathrm{dL}$ ), $61.8 \%$ of males $(n=1710)$ and $53.9 \%$ of females $(n=1989)$ were hyperlipidemia. The blood Hg levels were significantly higher in the hyperlipidemia group (male: $4.03 \mu \mathrm{g} / \mathrm{L}$, female: $2.83 \mu \mathrm{g} / \mathrm{L}$ ) compared to the non-hyperlipidemia group (male: $3.48 \mu \mathrm{g} / \mathrm{L}$, female: $2.69 \mu \mathrm{g} / \mathrm{L}$ ).

Table 3. The geometric means of blood $\mathrm{Hg}$ and the associations with hyperlipidemia (unit: $\mu \mathrm{g} / \mathrm{L}$ ).

\begin{tabular}{|c|c|c|c|c|c|c|c|c|}
\hline \multirow{2}{*}{\multicolumn{2}{|c|}{ Lipid Profiles }} & \multirow{2}{*}{ Criteria } & \multicolumn{2}{|c|}{ Male } & \multicolumn{2}{|c|}{ Female } & \multirow{2}{*}{$p$-Value ${ }^{a}$} & \multirow{2}{*}{$p$-Value ${ }^{b}$} \\
\hline & & & $\mathbf{N}$ & GM & $\mathbf{N}$ & GM & & \\
\hline \multirow[t]{5}{*}{ LDL } & $<100$ & Optimal & 1640 & 3.70 & 1982 & 2.70 & 0.0009 & 0.1054 \\
\hline & $100-129$ & Above optimal & 791 & 3.85 & 1161 & 2.84 & & \\
\hline & 130-159 & Borderline high & 285 & 4.31 & 434 & 2.80 & & \\
\hline & $160-189$ & High & 40 & 4.19 & 95 & 3.13 & & \\
\hline & $\geq 190$ & Very high & 11 & 4.05 & 15 & 2.79 & & \\
\hline \multirow[t]{3}{*}{ HDL } & $<40$ & Low & 552 & 3.53 & 321 & 2.59 & 0.0004 & 0.1730 \\
\hline & $40-60$ & Optimal & 1658 & 3.87 & 2023 & 2.77 & & \\
\hline & $\geq 60$ & High & 557 & 3.92 & 1343 & 2.82 & & \\
\hline \multirow{3}{*}{$\begin{array}{c}\text { Total } \\
\text { cholesterol }\end{array}$} & $<200$ & Desirable & 1955 & 3.64 & 2504 & 2.71 & $<0.0001$ & $<0.0001$ \\
\hline & $200-239$ & Borderline high & 654 & 4.28 & 909 & 2.86 & & \\
\hline & $\geq 240$ & High & 158 & 4.13 & 274 & 2.95 & & \\
\hline \multirow[t]{4}{*}{ TG } & $<150$ & Normal & 1286 & 3.59 & 2235 & 2.73 & $<0.0001$ & $<0.0001$ \\
\hline & 150-199 & Borderline high & 519 & 4.01 & 599 & 2.71 & & \\
\hline & $200-499$ & High & 854 & 4.00 & 794 & 2.94 & & \\
\hline & $\geq 500$ & Very high & 107 & 4.02 & 58 & 2.63 & & \\
\hline \multirow{2}{*}{\multicolumn{2}{|c|}{ Hyperlipidemia $^{c}$}} & No & 1057 & 3.48 & 1698 & 2.69 & $<0.0001$ & $<0.0001$ \\
\hline & & Yes & 1710 & 4.03 & 1989 & 2.83 & & \\
\hline
\end{tabular}

Note: GM, geometric mean; LDL, low-density lipoprotein; HDL, high-density lipoprotein; TG, triglyceride. ${ }^{a} p$-Value obtained using two-way ANOVA of the lipid profiles and sex. ${ }^{b} p$-Value obtained by ANCOVA adjusted for age.

${ }^{c}$ Hyperlipidemia was identified according to the following criteria - LDL $\geq 130$, total cholesterol $\geq 200$, or TG $\geq 150$.

\subsection{Association between Blood $\mathrm{Hg}$ and the Hepatic Enzymes}

The blood Hg levels were higher in participants who fell outside of the reference range for the hepatic enzymes (Table 4). The levels differed significantly by sex, and the significance remained after adjustment for age. According to the criteria for elevated liver enzymes, $24.3 \%$ of males $(n=671$; ALT $>49 \mathrm{U} / \mathrm{L}, \mathrm{AST} \geq 34 \mathrm{U} / \mathrm{L}$, or GGT $\geq 73)$ and $14.0 \%$ of females $(n=518 ;$ ALT $>49 \mathrm{U} / \mathrm{L}, \mathrm{AST} \geq 34 \mathrm{U} / \mathrm{L}$, or GGT $\geq 38$ ) had elevated liver enzymes. The blood $\mathrm{Hg}$ levels were significantly higher in the elevated liver enzymes group (male: $4.36 \mu \mathrm{g} / \mathrm{L}$, female: $3.25 \mu \mathrm{g} / \mathrm{L}$ ) compared to the normal liver enzymes group (male: $3.64 \mu \mathrm{g} / \mathrm{L}$, female: $2.70 \mu \mathrm{g} / \mathrm{L}$ ). 
Table 4. The geometric means of blood $\mathrm{Hg}$ and the associations with elevated liver enzymes (unit: $\mu \mathrm{g} / \mathrm{L}$ ).

\begin{tabular}{|c|c|c|c|c|c|c|c|c|}
\hline \multirow{2}{*}{$\begin{array}{l}\text { Hepatic } \\
\text { Enzymes }\end{array}$} & \multicolumn{3}{|c|}{ Male } & \multicolumn{3}{|c|}{ Female } & \multirow{2}{*}{$p$-Value ${ }^{a}$} & \multirow{2}{*}{$p$-Value ${ }^{b}$} \\
\hline & Criteria & $\mathbf{N}$ & GM & Criteria & $\mathbf{N}$ & GM & & \\
\hline \multirow{2}{*}{ ALT } & $\leq 49$ & 2513 & 3.78 & $\leq 49$ & 3583 & 2.75 & \multirow[t]{2}{*}{$<0.0001$} & \multirow[t]{2}{*}{$<0.0001$} \\
\hline & $>49$ & 254 & 4.14 & $>49$ & 104 & 3.56 & & \\
\hline \multirow{2}{*}{ AST } & $<34$ & 2373 & 3.76 & $<34$ & 3446 & 2.74 & \multirow[t]{2}{*}{$<0.0001$} & \multirow[t]{2}{*}{$<0.0001$} \\
\hline & $\geq 34$ & 394 & 4.14 & $\geq 34$ & 241 & 3.22 & & \\
\hline \multirow{2}{*}{ GGT } & $<73$ & 2361 & 3.67 & $<38$ & 3305 & 2.71 & \multirow[t]{2}{*}{$<0.0001$} & \multirow[t]{2}{*}{$<0.0001$} \\
\hline & $\geq 73$ & 406 & 4.73 & $\geq 38$ & 382 & 3.30 & & \\
\hline Elevated & No & 2096 & 3.64 & No & 3169 & 2.70 & \multirow[t]{2}{*}{$<0.0001$} & \multirow[t]{2}{*}{$<0.0001$} \\
\hline Liver enzymes $^{c}$ & Yes & 671 & 4.38 & Yes & 518 & 3.25 & & \\
\hline
\end{tabular}

Note: GM, geometric mean; ${ }^{a} p$-Value obtained by two-way ANOVA of the hepatic enzymes and sex. ${ }^{b} p$-Value obtained by ANCOVA adjusted for age. ${ }^{c}$ Elevated liver enzymes were identified according to the following criteria - ALT $>49$, AST $\geq 34$, or GGT $\geq 73$ for males, and ALT $>49$, AST $\geq 34$, or GGT $\geq 38$ for females.

\subsection{The Risks of Hyperlipidemia and Elevated Liver Enzymes}

Figure 1 shows the number of participants reporting personal medications; 317 (4.91\%) reported hyperlipidemia, 1175 (18.2\%) reported hypertension, and 539 (8.35\%) reported diabetes. One hundred and forty-four subjects took medication for hyperlipidemia and hypertension, both. And 49 subjects indicated that they took medication for hyperlipidemia, hypertension, and diabetes. Increased blood $\mathrm{Hg}$ was associated with a 1.105-fold increase in the odds of hyperlipidemia (95\% CI: 1.013, 1.208) (Table 5). Thus, an increase of $1 \mu \mathrm{g} / \mathrm{L}$ blood $\mathrm{Hg}$ was associated with an $11 \%$ risk of hyperlipidemia. The significance of the odds ratio (OR) estimates remained even after adjustment for personal medications related to hyperlipidemia. For those participants reporting hyperlipidemia and diabetes, the blood $\mathrm{Hg}$ GM was $3.60 \mu \mathrm{g} / \mathrm{L}$, and blood $\mathrm{Hg}$ was associated with a 1.105-fold increase in the odds of hyperlipidemia (95\% CI: 1.013, 1.207). This remained after adjusting for personal medications (hyperlipidemia and diabetes).

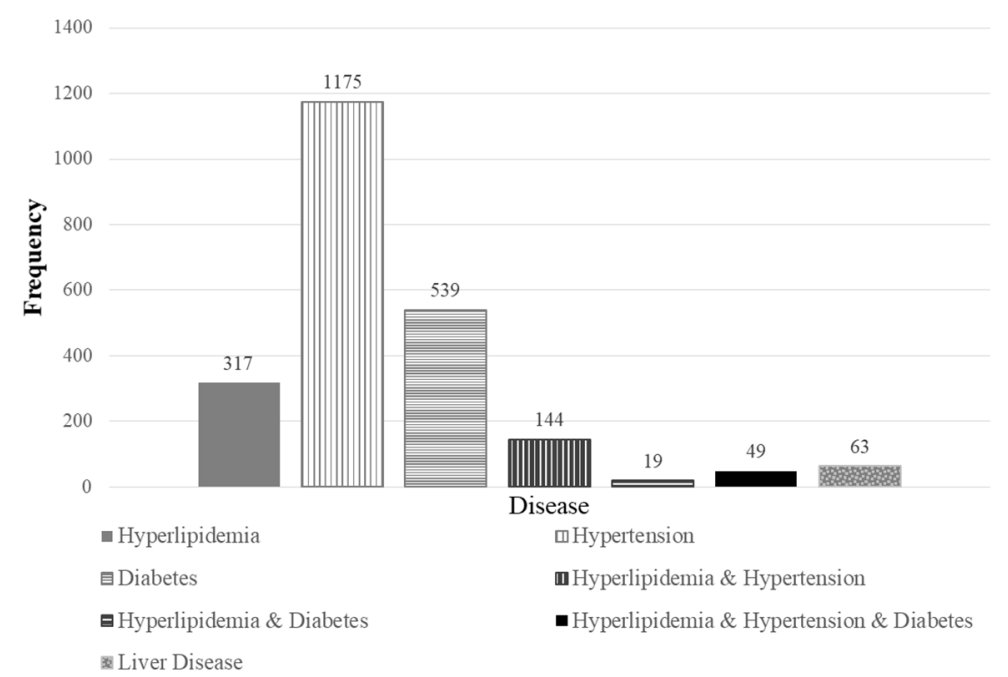

Figure 1. Frequency of the reported personal medications. Hyperlipidemia-associated diseases were extracted with the terms 'hyperlipidemia', 'dyslipidemia', 'high blood pressure', 'hypertension', and 'diabetes'. Liver diseases were categorized with the terms 'fatty liver', 'hepatitis', 'liver cirrhosis', 'liver disease', and 'elevated liver enzymes'. 
Table 5. The relationships between blood $\mathrm{Hg}$ and hyperlipidemia and elevated liver enzymes.

\begin{tabular}{|c|c|c|c|c|c|}
\hline Disease & Personal Medication ${ }^{a}$ & GM & OR & $95 \% \mathrm{CI}$ & $p$-Value ${ }^{b}$ \\
\hline \multicolumn{6}{|c|}{ Hyperlipidemia $(n=3699)$} \\
\hline & Unadjusted & 3.33 & 1.105 & $(1.013,1.206)$ & 0.0252 \\
\hline & Hyperlipidemia & 3.12 & 1.104 & $(1.012,1.206)$ & 0.0266 \\
\hline & $\begin{array}{l}\text { Hyperlipidemia and } \\
\text { Hypertension }\end{array}$ & 2.95 & 1.104 & $(1.011,1.205)$ & 0.0275 \\
\hline & Hyperlipidemia and Diabetes & 3.60 & 1.105 & $(1.013,1.207)$ & 0.0250 \\
\hline & $\begin{array}{c}\text { Hyperlipidemia and } \\
\text { Hypertension and Diabetes }\end{array}$ & 3.16 & 1.104 & $(1.012,1.206)$ & 0.0263 \\
\hline & $\begin{array}{l}\text { One of the Hyperlipidemia, } \\
\text { Hypertension, Diabetes }\end{array}$ & 3.19 & 1.100 & $(1.007,1.201)$ & 0.0335 \\
\hline \multicolumn{6}{|c|}{ Elevated liver enzymes $(n=1189)$} \\
\hline & Unadjusted & 3.84 & 1.345 & $(1.206,1.500)$ & $<0.0001$ \\
\hline & Liver disease & 3.24 & 1.350 & $(1.210,1.506)$ & $<0.0001$ \\
\hline
\end{tabular}

Note: GM, geometric mean; OR, odds ratio; 95\% CI, 95\% confidence interval. ${ }^{a}$ Personal medication information was included in the model from the self-reported response. ${ }^{b} p$-Value shows the significance of the odds ratio of blood $\mathrm{Hg}$ from logistic regression. The unadjusted model included the main effects of sex, age, BMI, smoke, alcohol frequency, fish consumption, and the two-way interaction of sex and alcohol frequency. Each personal medication information was included in the unadjusted model.

Sixty-three $(0.98 \%)$ participants reported fatty liver, hepatitis, cirrhosis, liver disease, increased hepatic enzymes, or other liver-related diseases. Increased blood Hg induced a 1.345-fold increase in the odds of elevated liver enzymes (95\% CI: 1.206, 1.500). Thus, high blood Hg induced a 35\% greater odds of elevated liver enzymes. After adjustment for personal medications related to liver diseases, the OR showed a 1.350-fold risk of elevated liver enzymes.

\subsection{Relationships between the Lipid Profiles and Hepatic Enzymes across Blood Hg Groups}

The correlations between the lipid profiles and hepatic enzymes in each blood Hg group are presented in Figure 2. In general, the correlation coefficients showed no associations between the hepatic enzymes and lipid profiles, except for TG. The correlation coefficients between log TG and log hepatic enzymes were 0.28 for ALT, 0.14 for AST, and 0.35 for GGT, and did not differ across blood Hg levels. 


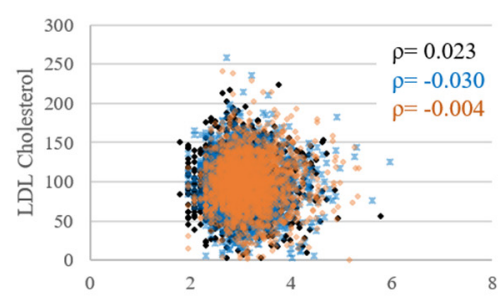

$\log$ ALT

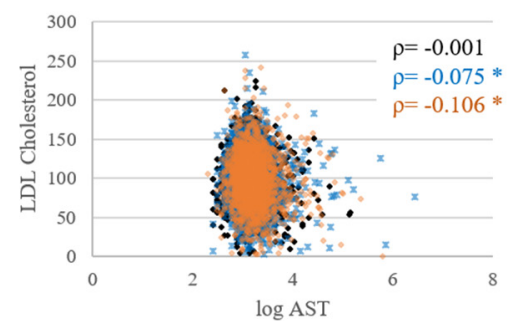

$\log$ AST

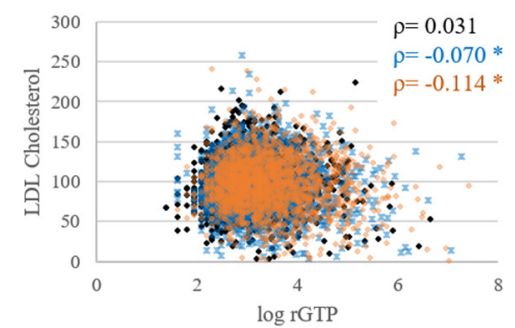

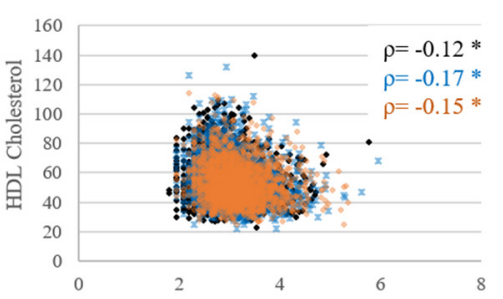

$\log$ ALT
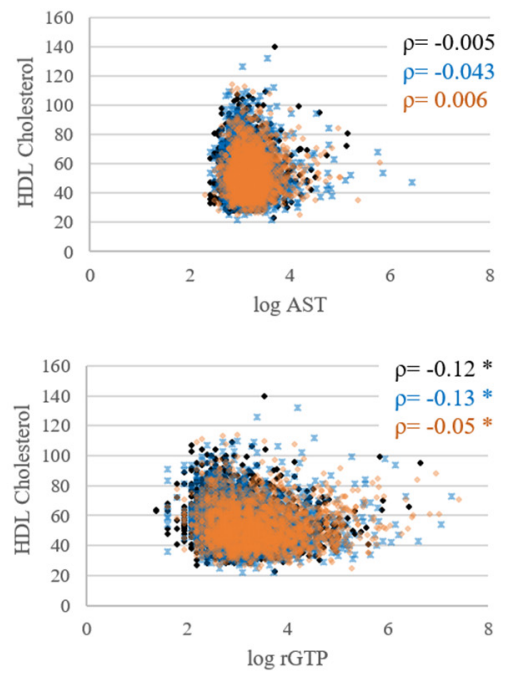

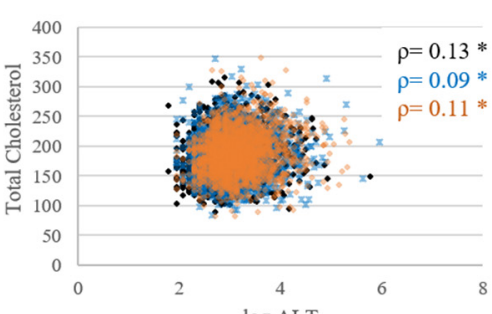

$\log$ ALT

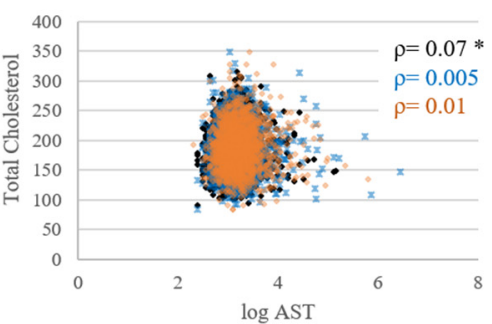

$\log$ AST

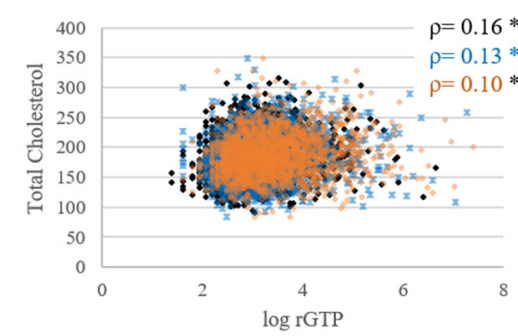

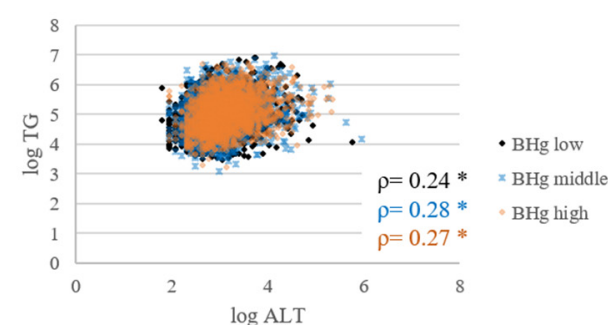
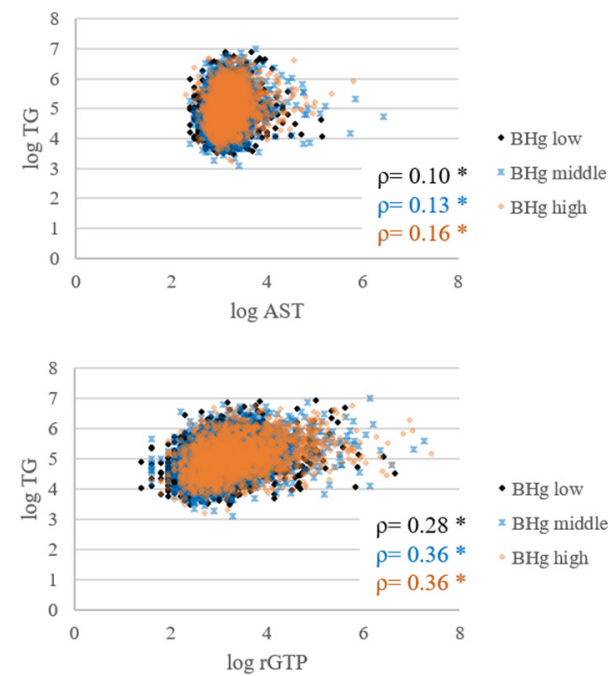

Figure 2. Correlations between the lipid profiles and hepatic enzymes in each blood $\mathrm{Hg}$ group. The x-axes represent the natural log scale of hepatic enzymes, and the $y$-axes represent the lipid profiles including natural log scale of TG. The black, blue, and orange colors indicate low, middle, and high blood Hg levels, respectively. ' $\rho$ ' represents the correlation coefficient, and * indicates the significance of the correlation coefficient $(p<0.05)$. BHg on the left side of the figure indicates blood Hg. 


\section{Discussion}

This study used the second cycle of the KoNEHS (2012-2014) to examine the obesogenic properties of blood Hg as it relates to hyperlipidemia and elevated liver enzymes. The GM of blood Hg was high, up to $3.11 \mu \mathrm{g} / \mathrm{L}$, and $57.3 \%$ of the survey population had hyperlipidemia. For participants aged 40 and above, $55-66 \%$ had hyperlipidemia, whereas $38 \%$ of the participants in their 20 s and $50 \%$ of the participants in their 30s had hyperlipidemia. The mean BMI of the hyperlipidemia group was 25.0 compared to 23.3 in the non-hyperlipidemia group. Moreover, the mean BMI was 24.0 in the normal group and 25.7 in the elevated liver enzymes group.

Approximately $32.1 \%$ of males $(n=889)$ and $15.4 \%$ of females $(n=566)$ had blood Hg levels over $5.00 \mu \mathrm{g} / \mathrm{L}$, which is the acceptable level for no adverse effects (HBM-I) [22]. These results are consistent with the first cycle of the KoNEHS (2009-2011), where 33.4\% of males and 16.1\% of females exceeded the HBM-I [10]. Many studies have investigated the high blood $\mathrm{Hg}$ levels in the Korean population. Some reported significant associations between $\mathrm{Hg}$, high BMI, and metabolic syndromes [23,24], while others reported no associations or even negative associations [25-27]. Metabolic syndromes are associated with many factors, including dietary habits and living patterns, and some factors may have a stronger influence than $\mathrm{Hg}$ exposure. For example, alcohol consumption is a major risk factor for metabolic syndromes, and raw-fish and clam soup are popular menu items that are often consumed with alcohol in Korea. Thus, blood Hg is also significantly associated with drinking alcohol, and the frequency of alcohol intake should be accounted for when evaluating the relationship between $\mathrm{Hg}$ exposure and metabolic syndromes in Korea. In our study, $62.3 \%$ of males and $20.9 \%$ of females drank alcohol more than once a week. Therefore, we also included the interaction of alcohol consumption frequency and sex $(p<0.0001$ for hyperlipidemia) when examining the obesogenic effects of $\mathrm{Hg}$.

It is also possible that individual treatments for obesity attenuate the effects of $\mathrm{Hg}$ exposure. Those diagnosed with metabolic syndromes may actively control their lipid profiles and insulin resistance. Therefore, treatments including personal medications, could affect the associated markers and the diagnoses of metabolic syndromes. In the Table 5, we showed only the ORs of blood Hg after each medication. And the same analyses provided that taking personal medications for hyperlipidemia reduced the odds of hyperlipidemia by $29 \%$ (OR: $0.710,95 \%$ CI: $0.559,0.902$ ), and taking personal medications for hyperlipidemia, hypertension, and diabetes was associated with $59 \%$ lower odds of hyperlipidemia (OR: 0.410, 95\% CI: 0.029, 0.733). Nonetheless, Hg significantly affected to the odds of having hyperlipidemia.

Among the different forms of $\mathrm{Hg}$, alkyl $\mathrm{Hg}$ is more lipid soluble and passes readily through biological membranes [28]. Especially, methylmercury ( $\mathrm{MeHg}$ ) among the alkyl $\mathrm{Hg}$, is the dominant form in human blood [29] because the primary exposure source for the general population is fish consumption. MeHg exposure inhibits paraoxonase-1, which prevents the atherosclerotic process by metabolizing toxic oxidized lipids associated with LDL and HDL [30]. Therefore, Hg induces oxidative stress and disrupts gluconeogenesis, resulting in systemic inflammation that affects the accumulation of abnormal adipocytes [23,31]. Our results showed that the levels of blood Hg were significantly higher $(p<.0001)$ in the hyperlipidemia group (male: $4.03 \mu \mathrm{g} / \mathrm{L}$, female: $2.83 \mu \mathrm{g} / \mathrm{L}$ ) than in the non-hyperlipidemia group (male: $3.48 \mu \mathrm{g} / \mathrm{L}$, female: $2.69 \mu \mathrm{g} / \mathrm{L}$ ), and that an increase of $1 \mu \mathrm{g} / \mathrm{L}$ blood $\mathrm{Hg}$ was associated with an $11 \%$ increase in the odds of hyperlipidemia, even after adjustment for personal medications.

Though bile is the major route of excretion, $\mathrm{Hg}$ can be reabsorbed into the blood via the enterohepatic system [12,32]. In particular, methylated $\mathrm{Hg}$ makes up most of the mercury in humans and can easily bind to cysteine residues [33], such as glutathione, and penetrate the cellular membranes [34]. The MeHg-cysteine complex can then enter the bile tract and be hydrolyzed by GGT and other dipeptides $[13,33]$. As a result, $\mathrm{Hg}$ induces hydrogen peroxide, depletes glutathione, and increases GGT levels. The association between Hg exposure and GGT, a marker of oxidative stress, is supported by several animal and human studies [35-37]. Our study also showed that the levels of blood $\mathrm{Hg}$ were significantly higher $(p<0.0001)$ in the elevated liver enzymes group (male: $4.36 \mu \mathrm{g} / \mathrm{L}$, female: 
$3.25 \mu \mathrm{g} / \mathrm{L}$ ) compared to the normal group (male: $3.64 \mu \mathrm{g} / \mathrm{L}$, female: $2.70 \mu \mathrm{g} / \mathrm{L}$ ). After adjustment for personal medications, blood $\mathrm{Hg}$ was associated with $35 \%$ higher odds of elevated liver enzymes.

This study has several limitations and strengths. The study design is a cross-sectional survey, and each measurement was analyzed from an individual spot sample. However, the dataset is representative of the entire Korean population. According to the previous studies, the intra-class correlation for blood $\mathrm{Hg}$ was $0.67 \sim 0.71$ [38]. Moreover, diet is the major source of $\mathrm{Hg}$, so we anticipate that the individual blood $\mathrm{Hg}$ levels would be constant. Secondly, individual health status or medical history data were unavailable. Instead, personal medication data were adjusted for the obesogenic effects of $\mathrm{Hg}$. We also performed correlation analyses between the lipid profiles and hepatic enzymes to avoid overestimating the $\mathrm{Hg}$ effects. There were no associations between the lipid profiles and hepatic enzymes, nor were there any differences across blood Hg groups (Figure 2). This indicates that the effects of blood $\mathrm{Hg}$ on the lipid profiles were irrelevant to the hepatic enzymes and that the hepatic enzymes were not affected by the lipid profiles. Thus, correlation analyses demonstrate the significant effects of blood $\mathrm{Hg}$ on hyperlipidemia and elevated liver enzymes.

\section{Conclusions}

In this study, we investigated the obesogenic properties of blood $\mathrm{Hg}$ using lipid profiles and hepatic enzymes. Higher blood Hg levels were observed in the hyperlipidemia group than in the non-hyperlipidemia group, and the elevated liver enzymes group had higher mean blood Hg levels than the normal group. Blood $\mathrm{Hg}$ was associated with higher odds of hyperlipidemia and elevated liver enzymes, even after adjusting for personal medications. These results indicate that $\mathrm{Hg}$ exposure is associated with obesity-related outcomes and that other health effects due to low-level $\mathrm{Hg}$ exposure should be investigated.

Supplementary Materials: The following are available online at http://www.mdpi.com/2305-6304/8/3/47/s1, Table S1: Blood Hg distributions by influential variables.

Author Contributions: Conceptualization, S.L. and S.-R.C.; Methodology, I.J. and J.B.P.; Formal analysis, S.L.; Writing-Original Draft, S.L.; Writing-Review and Editing, M.-Y.S., S.-R.C., S.K., J.H.K.; Supervision, S.K. and J.H.K. All authors have read and agreed to the published version of the manuscript.

Funding: This research received no external funding.

Conflicts of Interest: The authors declare no conflict of interest.

\section{References}

1. Lee, S.E.; Han, K.; Kang, Y.M.; Kim, S.O.; Cho, Y.K.; Ko, K.S.; Park, J.Y.; Lee, K.U.; Koh, E.H. Taskforce Team of Diabetes Fact Sheet of the Korean Diabetes, A. Trends in the prevalence of metabolic syndrome and its components in South Korea: Findings from the Korean National Health Insurance Service Database (2009-2013). PLoS ONE 2018, 13, e0194490. [CrossRef]

2. Janesick, A.S.; Blumberg, B. Obesogens: An emerging threat to public health. Am. J. Obstet. Gynecol. 2016, 214, 559-565. [CrossRef] [PubMed]

3. Poursafa, P.; Ataee, E.; Motlagh, M.E.; Ardalan, G.; Tajadini, M.H.; Yazdi, M.; Kelishadi, R. Association of serum lead and mercury level with cardiometabolic risk factors and liver enzymes in a nationally representative sample of adolescents: The CASPIAN-III study. Environ. Sci. Pollut. Res. Int. 2014, 21, 13496-13502. [CrossRef] [PubMed]

4. Rothenberg, S.E.; Korrick, S.A.; Fayad, R. The influence of obesity on blood mercury levels for U.S. non-pregnant adults and children: NHANES 2007-2010. Environ. Res. 2015, 138, 173-180. [CrossRef] [PubMed]

5. National Institute of Environmental Research. Integrated Report on Korean National Environmental Health Survey-The 1st Stage (2009-2011); National Institute of Environmental Research: Incheon, Korea, 2011.

6. Centers for Disease Control and Prevention. Fourth National Report on Human Exposure to Environmental Chemicals, Updated Tables; Centers for Disease Control and Prevention: Atlanta, GA, USA, 2017; Volume 1. 
7. Health Canada. Fourth Report on Human Biomonitoring of Environmental Chemicals in Canada; Results of the Canadian Health Measures Survey Cycle 4 (2014-2015); Health Canada: Ottawa, ON, Canada, 2017.

8. Park, J.H.; Hwang, M.S.; Ko, A.; Jeong, D.H.; Kang, H.S.; Yoon, H.J.; Hong, J.H. Total mercury concentrations in the general Korean population, 2008-2011. Regul. Toxicol. Pharm. RTP 2014, 70, 681-686. [CrossRef] [PubMed]

9. Kim, N.Y.; Ahn, S.J.; Ryu, D.Y.; Choi, B.S.; Kim, H.; Yu, I.J.; Park, J.D. Effect of lifestyles on the blood mercury level in Korean adults. Hum. Exp. Toxicol. 2013, 32, 591-599. [CrossRef] [PubMed]

10. Lee, S.; Tan, Y.M.; Phillips, M.B.; Sobus, J.R.; Kim, S. Estimating Methylmercury Intake for the General Population of South Korea Using Physiologically Based Pharmacokinetic Modeling. Toxicol. Sci. 2017, 159, 6-15. [CrossRef]

11. Mergler, D.; Anderson, H.A.; Chan, L.H.; Mahaffey, K.R.; Murray, M.; Sakamoto, M.; Stern, A.H. Panel on Health, R.; Toxicological Effects of, M. Methylmercury exposure and health effects in humans: A worldwide concern. Ambio 2007, 36, 3-11. [CrossRef]

12. Hong, Y.S.; Kim, Y.M.; Lee, K.E. Methylmercury exposure and health effects. J. Prev. Med. Public Health 2012, 45, 353-363. [CrossRef]

13. Kim, S.-J.; Han, S.-W.; Lee, D.-J.; Kim, K.-M.; Joo, N.-S. Higher Serum Heavy Metal May Be Related with Higher Serum gamma-Glutamyltransferase Concentration in Koreans: Analysis of the Fifth Korea National Health and Nutrition Examination Survey (KNHANES V-1, 2, 2010, 2011). Korean J. Fam. Med. 2014, 35, 74-80. [CrossRef]

14. Oh, H.J.; Kim, T.H.; Sohn, Y.W.; Kim, Y.S.; Oh, Y.R.; Cho, E.Y.; Shim, S.Y.; Shin, S.R.; Han, A.L.; Yoon, S.J. Association of serum alanine aminotransferase and $\gamma$-glutamyltransferase levels within the reference range with metabolic syndrome and nonalcoholic fatty liver disease. Korean J. Hepatol. 2011, 17, 27-36. [CrossRef] [PubMed]

15. Mason, J.E.; Starke, R.D.; Van Kirk, J.E. Gamma-glutamyl transferase: A novel cardiovascular risk biomarker. Prev. Cardiol. 2010, 13, 36-41. [CrossRef] [PubMed]

16. Nakanishi, N.; Suzuki, K.; Tatara, K. Serum gamma-glutamyltransferase and risk of metabolic syndrome and type 2 diabetes in middle-aged Japanese men. Diabetes Care 2004, 27, 1427-1432. [CrossRef] [PubMed]

17. Choi, W.; Kim, S.; Baek, Y.W.; Choi, K.; Lee, K.; Kim, S.; Yu, S.D.; Choi, K. Exposure to environmental chemicals among Korean adults-updates from the second Korean National Environmental Health Survey (2012-2014). Int. J. Hyg. Environ. Health 2017, 220, 29-35. [CrossRef] [PubMed]

18. National Institute of Environmental Research. Guideline for Biological Specimens Management on the Second Stage Korean National Environmental Health Survey; National Institute of Environmental Research: Incheon, Korea, 2014.

19. Friedewald, W.T.; Levy, R.I.; Fredrickson, D.S. Estimation of the concentration of low-density lipoprotein cholesterol in plasma, without use of the preparative ultracentrifuge. Clin. Chem. 1972, 18, 499-502. [CrossRef] [PubMed]

20. National Institutes of Health. Third Report of the National Cholesterol Education Program (NCEP) Expert Panel on Detection, Evaluation, and Treatment of High Blood Cholesterol in Adults (Adult Treatment Panel III) Final Report. Circulation 2002, 106, 3143-3421.

21. National Institute of Environmental Research. Manual for Laboratory Procedures on the Second Stage Korean National Environmental Health Survey (Heavy Metals); National Institute of Environmental Research: Incheon, Korea, 2015.

22. Schulz, C.; Angerer, J.; Ewers, U.; Kolossa-Gehring, M. The German Human Biomonitoring Commission. Int. J. Hyg. Environ. Health 2007, 210, 373-382. [CrossRef]

23. Eom, S.Y.; Choi, S.H.; Ahn, S.J.; Kim, D.K.; Kim, D.W.; Lim, J.A.; Choi, B.S.; Shin, H.J.; Yun, S.W.; Yoon, H.J.; et al. Reference levels of blood mercury and association with metabolic syndrome in Korean adults. Int. Arch. Occup. Environ. Health 2014, 87, 501-513. [CrossRef]

24. Bae, S.; Park, S.J.; Yeum, K.J.; Choi, B.; Kim, Y.S.; Joo, N.S. Cut-off values of blood mercury concentration in relation to increased body mass index and waist circumference in Koreans. J. Investig. Med. 2016, 64, 867-871. [CrossRef]

25. You, C.-H.; Kim, B.-G.; Kim, J.-M.; Yu, S.-D.; Kim, Y.-M.; Kim, R.-B.; Hong, Y.-S. Relationship between blood mercury concentration and waist-to-hip ratio in elderly Korean individuals living in coastal areas. J. Prev. Med. Public Health 2011, 44, 218. [CrossRef] 
26. Park, S.; Lee, B.K. Body fat percentage and hemoglobin levels are related to blood lead, cadmium, and mercury concentrations in a Korean Adult Population (KNHANES 2008-2010). Biol. Trace Elem. Res. 2013, 151, 315-323. [CrossRef]

27. Moon, S.S. Additive effect of heavy metals on metabolic syndrome in the Korean population: The Korea National Health and Nutrition Examination Survey (KNHANES) 2009-2010. Endocrine 2014, 46, $263-271$. [CrossRef] [PubMed]

28. IPCS. International Programme on Chemical Safety-Methylmercury; United Nations Environment Programme: Nairobi, Kenya; the International Labour Organisation and World Health Organization: Geneva, Switzerland, 1990; Available online: http://www.inchem.org/documents/ehc/ehc/ehc101.htm (accessed on 8 April 2019).

29. Jung, S.A.; Chung, D.; On, J.; Moon, M.H.; Lee, J.; Pyo, H. Correlation Between Total Mercury and Methyl Mercury-In Whole Blood of South Korean. Bull. Korean Chem. Soc. 2013, 34, 1101-1107. [CrossRef]

30. Ayotte, P.; Carrier, A.; Ouellet, N.; Boiteau, V.; Abdous, B.; Sidi, E.A.; Chateau-Degat, M.L.; Dewailly, E. Relation between methylmercury exposure and plasma paraoxonase activity in inuit adults from Nunavik. Environ. Health Perspect 2011, 119, 1077-1083. [CrossRef]

31. Maqbool, F.; Bahadar, H.; Niaz, K.; Baeeri, M.; Rahimifard, M.; Navaei-Nigjeh, M.; Ghasemi-Niri, S.F.; Abdollahi, M. Effects of methyl mercury on the activity and gene expression of mouse Langerhans islets and glucose metabolism. Food Chem. Toxicol. 2016, 93, 119-128. [CrossRef]

32. Agency for Toxic Substances and Disease Registry. Toxicological Profile for Mercury; Agency for Toxic Substances and Disease Registry: Atlanta, GA, USA, 1999.

33. Clarkson, T.W.; Vyas, J.B.; Ballatori, N. Mechanisms of mercury disposition in the body. Am. J. Ind. Med. 2007, 50, 757-764. [CrossRef] [PubMed]

34. Aschner, M.; Aschner, J.L. Mercury neurotoxicity: Mechanisms of blood-brain barrier transport. Neurosci. Biobehav. Rev. 1990, 14, 169-176. [CrossRef]

35. Singh, V.; Joshi, D.; Shrivastava, S.; Shukla, S. Effect of monothiol along with antioxidant against mercury-induced oxidative stress in rat. Indian J. Exp. Biol. 2007, 45, 1037-1044. [PubMed]

36. Wadaan, M.A. Effects of mercury exposure on blood chemistry and liver histopathology of male rats. J. Pharmacol. Toxicol. 2009, 4, 126-131. [CrossRef]

37. Schaefer, A.M.; Stavros, H.C.; Bossart, G.D.; Fair, P.A.; Goldstein, J.D.; Reif, J.S. Associations between mercury and hepatic, renal, endocrine, and hematological parameters in Atlantic bottlenose dolphins (Tursiops truncatus) along the eastern coast of Florida and South Carolina. Arch. Environ. Con. Tox. 2011, 61, 688-695. [CrossRef]

38. Lee, S.; Shin, M.; Hong, Y.C.; Kim, J.H. Temporal variability of blood lead, mercury, and cadmium levels in elderly panel study (2008-2014). Int. J. Hyg. Environ. Health 2017, 220, 407-414. [CrossRef] 